\title{
ADVANTAGES OF GEOSYNTHETICS OVER NATURAL MATERIALS IN LANDFILLS WITH COMPOSITE LINER SYSTEMS
}

\author{
Kent Von Maubeuge ${ }^{1}$, NAUE Gmbh \& Co. KG, Espelkamp, Germany, \\ kvmaubeuge@naue.com \\ Stephan Westhus ${ }^{2}$, NAUE GmbH \& Co. KG, Espelkamp, Germany, swesthus@naue.com \\ Pascal Bretin ${ }^{3}$, NAUE GmbH \& Co. KG, Espelkamp, Germany, pbretin@ naue.com
}

\begin{abstract}
Geosynthetics have been used in civil and environmental applications for many decades. Primarily functions include separation, filtration, drainage, reinforcement, protection and sealing. The decades have been witness to the most significant advances in geosynthetic design, manufacturing and installation techniques.

Beyond the basic awareness of the available products, the marked increased use of geosynthetics as a whole appears to have been driven by the many advantages geosynthetics have over traditional construction methods and materials. Advantages include the direct material cost savings, airspace savings for landfills, the reduction of excavation volumes, faster installation rates, improved performance as well as the possibility of steeper slope applications. However, with the technical advances, greater care must be used to ensure the correct product is selected and just as importantly, that the product is properly installed. Poor selection or installation can have the effect of negating the economic and technical benefits.
\end{abstract}

\section{Introduction}

It is now common practice in most industrialized countries to use composite liner systems comprised of clay and synthetic components for solid and hazardous waste disposal applications. Depending upon the regulations and design requirements, these systems are used to minimize the inflow of surface water into the waste body, the outflow of leachate from the cell and to control the escape of landfill gas.

Composite landfill liners have traditionally been designed to use an aggregate leachate drainage layer and a geotextile cushion over an HDPE geomembrane (1.5 to $2.5 \mathrm{~mm}$ or 60 to 100 mils). This system has typically been installed directly over a compacted clay liner (CCL) subgrade, 50 to $100 \mathrm{~cm}$ in thickness. Landfill closures utilizing composite liner designs also commonly use $30 \mathrm{~cm}$ sand gas venting layers and thick compacted clay layers in conjunction with various flexible geomembranes such as a Linear Low Density Polyethylene.

More recently, geosynthetic clay liners (GCLs) have found their way into these composite liner designs, where they have been used in lieu of the CCL component. During this same period, drainage geocomposites, comprised of geonets bonded on one or both sides with geotextiles, also made great strides in replacing the thick sand layers as well as the individual components themselves, which were previously installed separately when interfacial shear strength was not at issue.

GCLs present numerous advantages over CCLs. They take up less airspace (5 to $10 \mathrm{~mm}$ thickness), are resistant to freeze/thaw and wet/dry cycles, can be installed quicker at substantially lower costs, they reduce on site QC/QA, and offer equivalent or better hydraulic characteristics depending upon the thickness and quality of the CCL replaced. 
Drainage geocomposites exhibit a comparably thin cross section that also measures roughly 5 to $10 \mathrm{~mm}$, depending upon the geotextiles and geonets used in their manufacture. They too maximize landfill airspace by replacing the typical $30 \mathrm{~cm}$ thick sand or aggregate drainage and /or gas venting layers. In cases where it is particularly difficult to install natural drainage layers on steep slopes, synthetic drainage layers can be an extremely viable alternative.

With our advancing knowledge of the capabilities of these products and the decreasing availability of economically obtainable, high quality, natural resources, it is a logical step to utilize geosynthetic materials wherever possible. The key is if they can be substituted into applications without sacrificing the integrity of the design or loss of performance.

\section{Geosynthetic Clay Liners Versus Compacted Clay Liners}

Before the widespread use of composite liner systems, it was common for geomembranes or compacted clay liners to be relied upon as the sole hydraulic barrier for landfill base liners and closures. While this approach is still used in some cases, the CCL is often being replaced by a GCL component. With more than one choice for the clay component, the options need to be examined to determine what product will most suitably address the needs of the project. Table 1 provides a general point / counterpoint comparison of a GCL when contrasted to a CCL.

Table 1: Advantages and Disadvantages of Clay Based Liners adapted from Daniel (1995)

\begin{tabular}{|c|c|c|}
\hline Material & Advantages & Disadvantages \\
\hline $\begin{array}{l}\text { Compacted } \\
\text { Clay Liner }\end{array}$ & $\begin{array}{l}\text { 1. Long history of (successful?) use. } \\
\text { 2. Regulatory approval is virtually } \\
\text { assured. } \\
\text { 3. Thickness ensures that layer will not } \\
\text { be breached by puncture. } \\
\text { 4. Thickness provides physical } \\
\text { separation between waste and } \\
\text { surface environment. } \\
\text { 5. Cost can be low if material is } \\
\text { locally available. } \\
\text { 6. Greater capacity for attenuation. } \\
\text { 7. Familiar material to geologists and } \\
\text { geotechnical engineers. }\end{array}$ & $\begin{array}{l}\text { 1. Susceptible to desiccation cracking. } \\
\text { 2. Must be protected from freezing. } \\
\text { 3. Very low resistance to cracking } \\
\text { from differential settlement. } \\
\text { 4. Difficult to compact soil above } \\
\text { compressible waste. } \\
\text { 5. Suitable quality borrow source not } \\
\text { always locally available. } \\
\text { 6. Difficult to repair if damaged. } \\
\text { 7. Slow construction. } \\
\text { 8. Flow likely through preferential } \\
\text { flow paths (macrostructures). } \\
\text { 9. Sensitive to construction. } \\
\text { 10. Potential concerns over interface } \\
\text { shear strengths. }\end{array}$ \\
\hline
\end{tabular}




\begin{tabular}{|c|c|c|}
\hline GCL & $\begin{array}{l}\text { 1. Rapid installation. } \\
\text { 2. Very low hydraulic conductivity to } \\
\text { water if properly installed. } \\
\text { 3. Low, predictable cost } \\
\text { 4. Excellent freeze/thaw resistance. } \\
\text { 5. Can withstand large differential } \\
\text { settlement. } \\
\text { 6. Excellent self- healing/sealing } \\
\text { characteristics. } \\
\text { 7. Manufactured highly quality } \\
\text { controlled consistency. } \\
\text { 8. Low volume consumed by liner. } \\
\text { 9. Easy to repair. } \\
\text { 10. Not as sensitive to installation. }\end{array}$ & $\begin{array}{l}\text { 1. Low shear strength of hydrated } \\
\text { bentonite / must be reinforced. } \\
\text { 2. Potential concerns over interface } \\
\text { shear strengths. } \\
\text { 3. GCLs can be punctured during or } \\
\text { after installation. } \\
\text { 4. Dry bentonite (e. g., at time of } \\
\text { installation) is not impermeable to } \\
\text { gas. }\end{array}$ \\
\hline
\end{tabular}

Table 1 illustrates the attributes of each type of clay liner material for a single liner design. It is unmistakable from even a basic comparison that the majority of significant benefits may be obtained with the GCL, and while not discussed in detail in this paper, typically at a lower cost than the CCL.

In composite liner systems where a clay liner is combined with a geomembrane the clay component of the composite liner must perform at the same minimum level as it would if used alone whether it is a GCL or a CCL. Therefore, the clay liner selection should be based on the best overall performing liner exhibiting the fewest deficiencies and the most positive attributes. While the most significant and arguably one of very few shortcomings of the GCL is its potential for puncture, a GCLs susceptibility to puncture is not a product defect or directly related to its installation. GCL puncture is associated with design or operational procedures subsequent to the liner system installation and can be controlled and/or minimized through operational procedures.

Forensic analysis indicates that leakage through geomembrane liners is often through seam defects and damage during its installation, Giroud (1989). While not to belittle concerns over puncture, proper installation techniques and construction/operational planning can suitably address these issues.

It is incumbent upon the designer as well as the GCL/CCL purchaser to base their decision on the attributes of the product within the design, not the events that occur after its installation. If the placement of an aggregate drainage layer is causing the damage, perhaps time would be better spent examining what can be done with the component causing the problem to minimize the damage / either through construction techniques and quality control or the use of alternative materials. Regardless, when the placement of cover soil, drainage aggregate or solid waste are properly planned, designed and implemented, puncture is no longer of significant consequence. A similar point / counterpoint examination of geomembranes provides an interesting similarity to GCLs in terms of the effects of the human element. Table 2 illustrates a few of the basic issues used to examine the GCL, put into the context of the geomembrane performance.

This is not to suggest that a GCL is an acceptable substitute for a geomembrane in a composite liner system or to infer there is a more appropriate material than high density polyethylene to use. However, the tables do illustrate that because a geomembrane is susceptible to comparable puncture concerns as the GCL, that the same liner system covering CQC and operational precautions should be exercised, regardless of the clay component selected in order to protect the integrity of the geomembrane. 
Table 2: General Advantages and Disadvantages of Geomembranes

\begin{tabular}{|l|l|l|}
\hline Material & Advantages & Disadvantages \\
\hline Geomembrane & 1. Rapid installation. & 1. Potential concerns over interface \\
2hear strengths.
\end{tabular}

\section{GCL versus CCL Survivability Comparison}

While it is obvious that a thin GCL can be damaged more easily than a thicker CCL, it is not as obvious that a moderately damaged GCL can still outperform a CCL. As GCLs are gaining increasing acceptance as substitutes for the CCL component of composite liners, it is useful to compare the predicted performance of the clay component options, when each is subjected to an uncorrected damaging event.

Using a mathematical model, the performance of a damaged CCL and a GCL are compared in Figure 1 and Tables 3(a) and 3(b), representing the worst case low normal load conditions of a landfill cap, which are to be evaluated for steady state leakage using Darcy's Law. It is assumed that the hydrated thickness of the GCL is $0.75 \mathrm{~cm}$, and that there is a confining stress over the GCL of approximately $13.8 \mathrm{kPa}$.

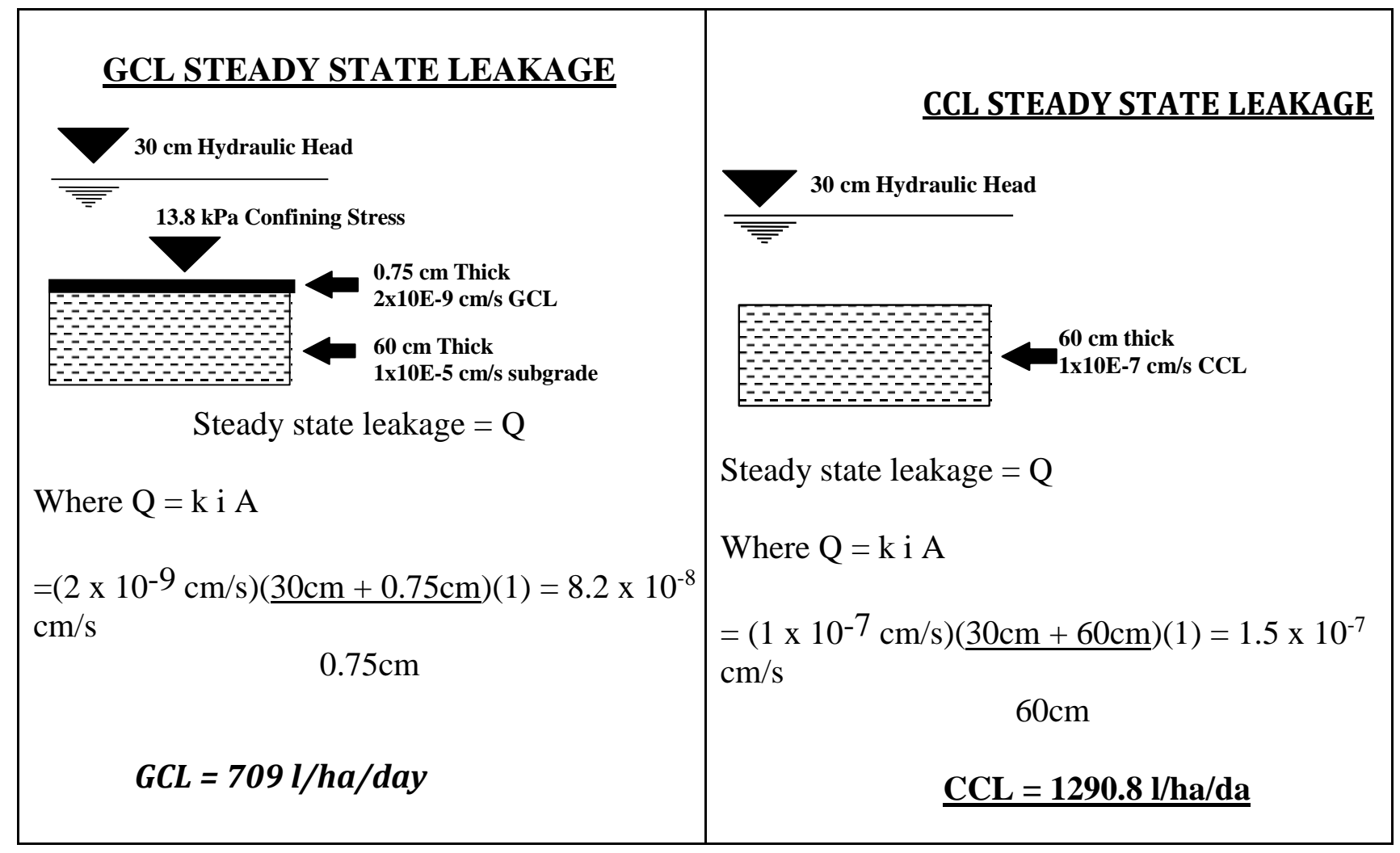

Figure 1 Illustration of GCL versus CCL Hydraulic performance 
With a few conservative assumptions, the calculations in Figure 1 demonstrate that the undamaged GCL will allow less leakage than a typical $60 \mathrm{~cm}(24$ inch) thick CCL when used on a landfill closure.

To fully explore the ramifications of a damaging event, we'll next assume that an equipment operator inadvertently gouges the liner during placement of the soil cover or drainage layer. The defect created is one square meter, $30 \mathrm{~cm}$ deep and is quickly buried by the equipment operator "to avoid trouble". The leakage through each liner due to these particular defects would be calculated as illustrated in Table 3(a).

Table 3(a): Flow Through Damaged Areas

\begin{tabular}{|c|c|}
\hline $\begin{array}{c}\text { LEAKAGE THROUGH GCL "DEFECT" ONLY } \\
\text { (Through remaining } 30 \mathrm{~cm} \text { layer of } 1 \times 10^{-5} \mathrm{~cm} / \mathrm{s} \\
\text { Subgrade) }\end{array}$ & $\begin{array}{c}\text { LEAKAGE THROUGH CCL "DEFECT" ONLY } \\
\text { (Through remaining } 30 \mathrm{~cm} \text { layer of } 1 \times 10^{-7} \mathrm{~cm} / \mathrm{s} \\
\text { CCL) }\end{array}$ \\
\hline $\begin{array}{l}\mathrm{Q}=\left(1 \times 10^{-5} \mathrm{~cm} / \mathrm{s}\right)\left(\frac{30 \mathrm{~cm}+30 \mathrm{~cm}}{\left.\mathrm{~cm}^{2}\right)}\right)(10,000 \\
30 \mathrm{~cm}\end{array}$ & $\begin{array}{c}\mathrm{Q}=\left(1 \times 10^{-7} \mathrm{~cm} / \mathrm{s}\right) \frac{(30 \mathrm{~cm}+30 \mathrm{~cm}}{30 \mathrm{~cm}}(1 \mathrm{sq} \mathrm{m}) \\
\mathbf{Q}=\mathbf{1 . 7} \mathbf{~} / \mathbf{d a y}\end{array}$ \\
\hline
\end{tabular}

In this particular case, the flow through the defect, inflicted by the equipment, is greater for the GCL than through a similar defect in a CCL. However, the total flow through each liner, which is the sum of the steady state flow and the defect related flow, must be calculated for a true comparison. Table 3(b) illustrates the total flow for each liner, including the increased flow through the covering operation induced defect.

Table 3(b): Flow Through Damaged Areas

\begin{tabular}{|ccc|ccc|}
\hline & \multicolumn{2}{c|}{ TOTAL GCL FLOW } & & \multicolumn{3}{c|}{ TOTAL CCL FLOW } & \\
\cline { 2 - 2 } $1 \mathrm{~m}$ & Flow & Total & $1 \mathrm{~m}$ & Flow & Total \\
$\begin{array}{c}\text { Defects } \\
\text { per Hectare }\end{array}$ & $\begin{array}{c}\text { Through Defect } \\
\text { S (1/day) }\end{array}$ & $\begin{array}{c}\text { Flow } \\
(1 / \text { ha/day) }\end{array}$ & $\begin{array}{c}\text { Defects } \\
\text { per }\end{array}$ & $\begin{array}{c}\text { Through Defect } \\
\text { S (1/day) }\end{array}$ & $\begin{array}{c}\text { Flow } \\
(1 / \text { ha/day) }\end{array}$ \\
0 & & & Hectare & & \\
1 & 0 & 709.0 & 0 & 0 & 1290.8 \\
2 & 170.3 & 879.3 & 1 & 1.7 & 1292.5 \\
3 & 340.6 & 1049.6 & 2 & 3.4 & 1294.2 \\
4 & 510.9 & 1219.9 & 3 & 5.1 & 1295.9 \\
& 681.2 & 1390.2 & 4 & 6.8 & 1297.6 \\
\hline
\end{tabular}

Table 3(b) demonstrates that it is necessary to have four equipment inflicted defects per hectare, each measuring of one square meter before the leakage of the GCL exceeds that of a defect free CCL.

As it is highly unlikely the GCL would be so severely damaged (even by the most careless operator), there is little reason to design a composite liner system with a CCL based on reasons of construction/installation survivability. In consideration of the long term deterioration of a CCL (due to settlement, freeze/thaw, and desiccation), the use of the GCL is by far the more attractive alternative. 


\section{Drainage Geocomposites, Sand and Gravel}

Drainage geocomposites can be manufactured with one or two filter and separation geotextiles attached to a geonet drainage core. While this paper is more focused towards geocomposites, many of these features can be obtained with individual geonets and geotextile combinations depending upon the frictional requirements.

Drainage geocomposites and systems are very similar to GCLs when thickness comparisons are made. They offer a manufactured alternative to a thicker component without the disadvantages of moving high volumes of earthen materials and thereby reduce the extensive transportation costs and associated issues of heavy truck traffic. For instance, approximately 300 truckloads of gravel would be required to cover $10,000 \mathrm{~m}^{2}$ with a $30 \mathrm{~cm}$ thick drainage layer. Only two truckloads of a drainage geocomposite would be required to cover the same area. If for no other reason, drainage geocomposites should be used just to lessen the environmental and traffic impact of the extra 298 trucks.

While the specific virtues of drainage geocomposites vary from product to product, the general virtues of earthen drainage/gas vent media versus drainage geocomposites are examined in Tables 4(a) and 4(b).

Table 4(a): Advantages and Disadvantages of Natural Drainage/Venting Layers

\begin{tabular}{|c|c|c|}
\hline Material & Advantages & Disadvantages \\
\hline \begin{tabular}{l}
\multicolumn{1}{c}{ Sand / } \\
Gravel \\
Drainage and \\
Gas Venting \\
Layers
\end{tabular} & $\begin{array}{l}\text { 1. Long history of use. } \\
\text { 2. Regulatory approval is } \\
\text { virtually assured. } \\
\text { 3. } \text { Thickness ensures drainage } \\
\text { layer will not become } \\
\text { significantly damaged. } \\
\text { 4. Lower gradients. } \\
\text { 5. Costs are low if material is } \\
\text { locally available. }\end{array}$ & 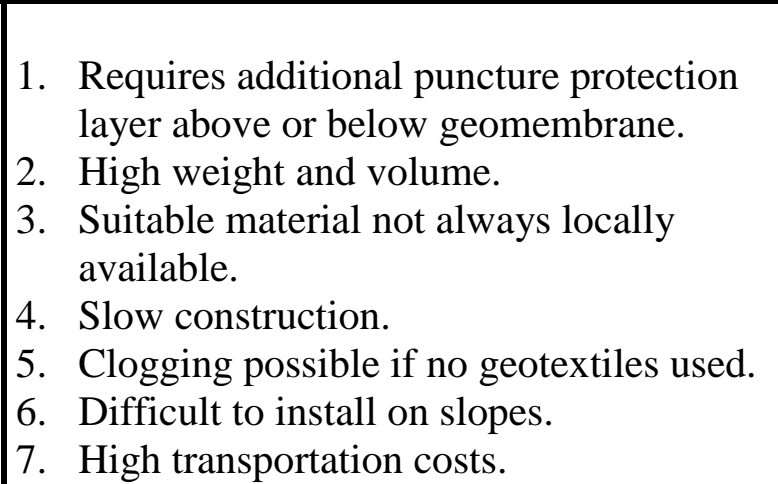 \\
\hline
\end{tabular}

While the GCL/CCL comparison indicated that puncture resistance of the GCL layer was the most significant "disadvantage", the puncturability of the drainage geocomposite is of negligible significance in comparison. When designing for steep slopes, the installation of aggregate drainage layers can be extremely difficult and potentially damaging to the underlying components. When the relative advantage of the natural material versus the geocomposite are compared from Tables 4(a) and 4(b), it can be concluded that drainage geocomposites provide many advantages over natural alternatives.

The geotextile components of drainage geocomposites must be selected to minimize the effects of clogging so that long term performance remains unimpaired. According to standard practice, the short term permeability of the geotextile filter should be 100 times greater than the permeability of the soil. Since drainage geocomposites are relatively thin, it is also extremely important to calculate the flow capacity limitations. Factors of safety should then applied to ensure the drainage capacity is greater than the inflow. However, regardless of the material selected, proper installation of the drainage geocomposite is the key to maximized performance. 
Table 4(b): Advantages and Disadvantages of Natural Drainage/Venting Layers

\begin{tabular}{|c|c|c|}
\hline Material & Advantages & Disadvantages \\
\hline $\begin{array}{l}\text { Drainage } \\
\text { Geocomposite }\end{array}$ & $\begin{array}{l}\text { 1. Rapid installation. } \\
\text { 2. Can also function as a protection } \\
\text { layer. } \\
\text { 3. Low and predictable costs. } \\
\text { 4. } \text { Can easily be installed on steep } \\
\text { slopes. } \\
\text { 5. Can withstand tensile strains. } \\
\text { 6. } \text { Low weight and volume. } \\
\text { 7. } \text { Correctly designed very effective } \\
\text { drain. }\end{array}$ & $\begin{array}{l}\text { 1. Potential concerns over } \\
\text { interface shear strengths. } \\
\text { 2. } \begin{array}{l}\text { Are susceptible to puncture } \\
\text { during or after installation. }\end{array} \\
\text { 3. } \begin{array}{l}\text { Drainage pipes may be } \\
\text { required in low slope } \\
\text { areas. }\end{array}\end{array}$ \\
\hline
\end{tabular}

\section{Multicomponent Geosynthetic Clay Liner for safe landfill caps}

Most recently, multi-component GCLs are introduced to the market. Either a thin plastic barrier is attached to one geotextile component of the GCL or a durable polyolefin polymer is firmly coated to the slit-film woven geotextile component of the GCL. This development enables GCLs to challenge particular site conditions where the use of GCLs has previously been limited.

The following definition proposals are currently being discussed in the ASTM D35 terminology task group and might be added in future in the ASTM terminology standard D4439.

multicomponent GCL, n - GCL with an attached film, coating, or membrane decreasing the hydraulic conductivity or protecting the clay core or both

adhered geosynthetic clay liner (GCL), $\mathrm{n}$ - GCL product in which the clay component is bonded to a film or membrane by adhesion

coated GCL, $n-$ GCL product with at least one layer of a synthetic substance applied to the GCL as a fluid and allowed to solidify

The polymer coating (fig.2) option of a new generation of multi-component GCLs is helping make GCL installations even more effective, safer and longer lasting. Especially they are uniformly applied over the entire surface directly as a fluid on top of the GCL and solidify by integrating the needle-punched fibres. Adhered films/membranes/laminates on the other hand have to be additionally glued to the GCL. This additionally added glue is not uniformly applied and the durable glueing against a polyethylene material is questionable. Further black coloured films/membranes/laminates throw waves under direct sunlight and hot temperature and are likely to delaminate glued films/membranes/laminates.

Advantages in utilising this polymer coating include the topics listed below, but are not limited to those. Prevention of Root Penetration: As plant and tree roots search for water, they spread in all directions horizontally and vertically, and will continue this search until they find enough water to sustain the plant. This search can impact a GCL installation. As described earlier, bentonite hydrates once in contact with fresh water, including moisture from the surrounding soil. Due to the bentonite's outstanding sorption capacity, the bentonite will typically have higher moisture content than the surrounding soil. 


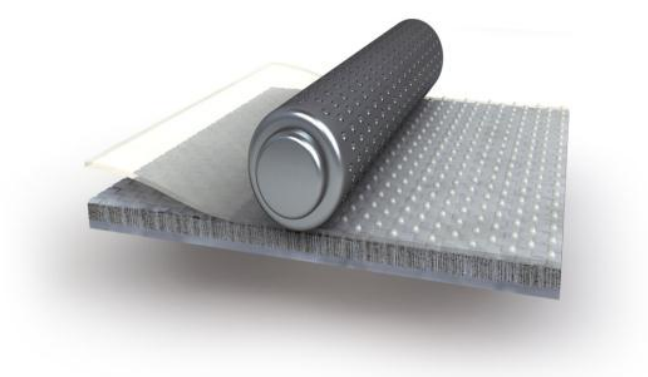

\section{Figure 2: Schematic of coating (with friction surface) being applied to a needle-punched GCL (NAUE)}

Roots can be attracted to this moisture. Though high-quality powdered sodium bentonite possesses self-sealing properties, root penetration should not be encouraged. Roots can extract water content from bentonite. Placing the polymer coated slit-film woven geotextile side against the direction of potential root growth will protect the hydrated bentonite core from root penetration - thus, maintaining a high bentonite moisture content and a high level of design safety and performance.

Increasing Resistance against Desiccation: According to soil mechanics, swellable and hydrated soils shrink when desiccating. In clays, this is typically revealed with cracking. The same mechanics can affect swellable bentonites. Such desiccation can occur in arid and semi-arid areas, in regions with low soil coverage or little rainfall, and in applications where the bentonite does not have constant access to fresh water. Even though needle-punched, fibre-reinforced GCLs will show a much smaller crack pattern than unreinforced or poorly reinforced GCLs, a desiccation crack pattern will increase fluid or gas permeation rates prior to the self-sealing of the bentonite (which occurs upon contact with fresh water). If this is not acceptable for the designed application, the polymer-coated GCL can be used with the polymer coating facing the direction of expected desiccation. In most cases, this will be the upper side of the GCL. The upside-facing polymer coating of the GCL would prevent moisture escape and allow the bentonite to be hydrated and act as a barrier, even in arid areas or under very low confining stresses (fig. 3).

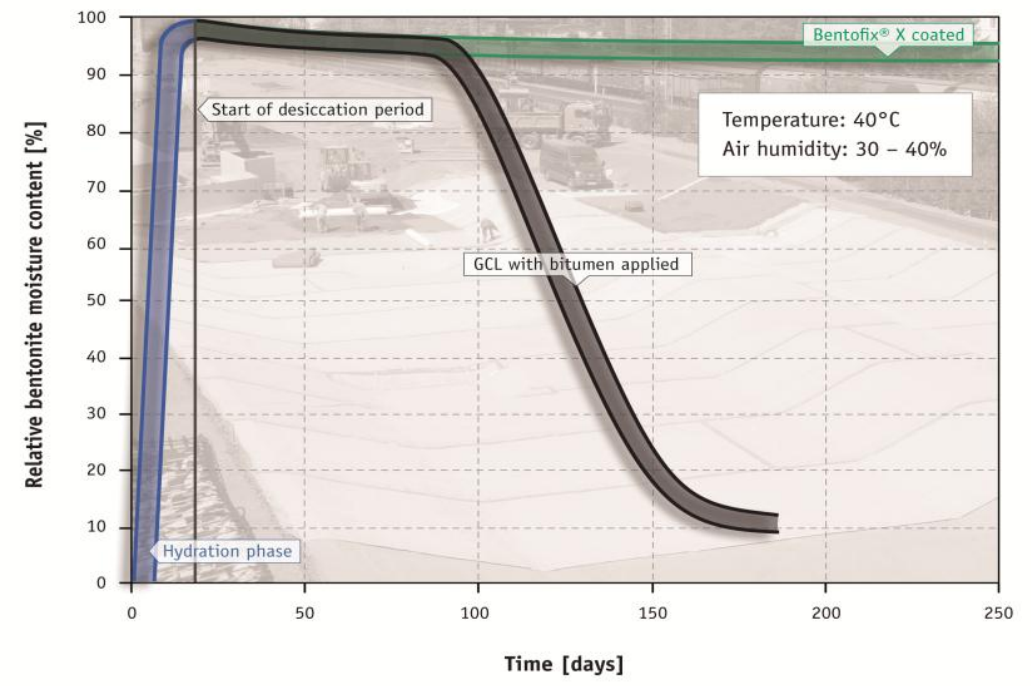

Figure 3: Desiccation behaviour of GCLs in a laboratory test (NAUE) 
Bentonite Piping Resistance under High Water Gradients: When placed over coarse grain soils or other open structures (such as geonets), a question remains as to whether bentonite extrusion or piping can occur under high hydraulic water conditions. Common applications of this nature include canals, ponds, and lagoons. Though needle-punched GCLs with scrim-reinforced nonwovens will provide under laboratory conditions the best performance against bentonite erosion (ROWE et al. 2003), the highest safety against this on-site condition involves the attachment of a polymer coating against the slit-film woven side of the GCL. Bentonite erosion with the coated side facing against the porous subgrade is now virtually impossible, even under high and extreme hydraulic conditions. The long-term sealing performance of the polymer coated GCL is ensured.

Lower Permeability: Needle-punched GCLs have a strong history as a stand-alone barrier, largely due to the high grade of powered sodium bentonite used in the GCL's construction. This sodium bentonite exhibits high swelling behavior, low water permeability, excellent water absorption and retention capacity, and a unique self-sealing/-healing effect. These exceptional capabilities of the bentonite remain, even with the use of a polymer coating on GCL. This extra coating simply adds its advantages to the GCL which increases the GCL performance. The coating improves overall performance while further lowering the permeability of the GCL. With these advantages now combined, needlepunched GCLs outperform nearly any sealing system in regard to hydraulic conductivity during the service life of the coating and beyond.

Barrier against Ion Exchange: When a GCL is in contact with fluids and soils containing leachable cations, such as calcium $(\mathrm{Ca})$, magnesium $(\mathrm{Mg})$, potassium $(\mathrm{K})$ or other polyvalent cations, an ion exchange of the sodium (Na) portion of the GCL can occur. If it does, the clay structure of the GCL core can be affected, which might impact the swelling capacity and the hydraulic conductivity performance. However, it is impossible to make general statements on the long-term performance of a GCL under these conditions. Using calcium bentonite instead as the sealing core in a GCL, even with a higher mass per unit area (e.g. 8 to $10 \mathrm{~kg}$ ), is not a suitable option. Published results (Henken-Mellies, 2010; Mueller-Kirchenbauer, 2010) have shown that the hydraulic conductivity results of calcium bentonite are far higher than ion exchanged sodium bentonite GCLs. In applications where this issue might be a concern, a polymer coating on the GCL facing the possible polyvalent cation source can help guard against this possible ion exchange. In most applications water, which is the hydration source for the bentonite, comes from the top and permeates through the soil layer above the GCL. In applications with soils that have a high concentration of free available leachable cations, a coated GCL is an ideal solution. The thin coating facing the source of exchangeable cations acts as a barrier and protects the sodium bentonite sealing core of the GCL.

Gas Barrier: In applications in which the GCL has to perform immediately as a gas barrier, the porous bentonite core might not have time to fully hydrate with water and fulfill its sealing performance due to immediate gas migration. Applications of this nature include the waterproofing of underground structures, landfill caps, and other applications in which the GCL is installed over an active source of gas production. The coated barrier of needlepunched GCL would act as the gas-impermeable barrier, thus allowing the installation and welding of a geomembrane. In this case the sealing of the coated overlaps of the GCL can easily be carried out with a special bituminous tape.

\section{Conclusions:}

There are significant economic and performance benefits derived from Geosynthetic Clay Liners and drainage geocomposites when selected for use over much thicker, natural materials. Natural 
resources and airspace volumes are preserved; construction volumes, traffic and transportation costs are reduced, construction timeframes are reduced; and performance can remain at the same level or higher. While the thickness of these geosynthetic components can lead to puncture related concerns, they are relatively unimportant issues when the construction of the liner system is properly designed, specified, and sequenced. Even when mistakes occur, the significantly higher performance of geosynthetics can minimize the impact to such a degree that unaffected natural materials do not perform as well. Of key importance are the quality control procedures utilized to ensure the liner system is not damaged when being covered. Covering operations should anticipate problems and have solutions to minimize placement related damage. Cover soil placement over geomembranes should be coordinated to minimize wrinkles by performing the operation during cooler periods of the day. With proper construction quality control (CQC) and construction quality assurance (CQA), anticipated performance can consistently be obtained.

\section{References:}

"Daniel, D. E.: State of the Art of U.S. Landfill Capping Systems, AGK 37, VDI Seminar, Karlsruhe, Germany", (1995)

"Giroud, J.P., Bonaparte, R.: Leakage through Liners Constructed with Geomembranes - Part - I. Geomembrane Liners \& Part - II. Composite Liners, Geotextiles and Geomembranes 8(1-2), pp. 27-67 \& pp. 71-111”, (1989)

W.U. Henken-Mellies; GCL in a landfill final cover: 10-year record of a lysimeter field test, 3rd International Symposium on Geosynthetic Clay Liners Würzburg, Germany, (2010)

A. Müller-Kirchenbauer, W. Blümel, K. P. von Maubeuge; Performance of Geosynthetic clay liners in landfill cap sealing systems - physical processes in the bentonite layer during drying and rehydration periods, 3rd International Symposium on Geosynthetic Clay Liners Würzburg, Germany, (2010)

NAUE (2013): "Advantages of needle-punched, PE-coated Bentofix X Geosynthetic Clay Liners”, Flyer \# 291 